\title{
The Role of the Bible in the Formation of Philosophical Thought in Kievan Rus' (AS EXEMPLIFIED BY ILARION OF KIEV, KLIMENT Smolatič, and Kirill of Turov)
}

The existence of philosophy in Kievan Rus' $\left(10^{\text {th }}-13^{\text {th }}\right.$ centuries) is a contro1 versial issue. We do not find there a philosophy in a sense of theoretical and rational reflection with abstract notions and schemes about the world and Man but we do find a philosophy understood as a love of wisdom (любомудрие). Wisdom at that time meant a great knowledge of the Bible, proficiency in allegorical interpretation of it, a certain worldview and an ethical attitude that enabled to set intellectual standards, to teach, to guide society and to create popular ideas. The concept of "книжность" partly covers the semantic field encompassing these activities and virtues. The Eastern and Southern Slavonic "книжник" was a scholar, (bookman) either a monk or a priest whose work laid foundations for the cultural development of the country.

The work of Ilarion of Kiev (ca. 990-1055), Kliment Smolatič († ca. 1164), and Kirill of Turov (1130-1182) fits within the concept of “жнижность" only partially and does not exhaust it. These men are the most representative though not the only figures in the theological (and thus philosophical) life of Kievan Rus' ${ }^{1}$. The period of their activity bears the name of the Golden Age due to enterprises extremely important for the nascent Rus' identity, such as the erection of St. Sophia's Cathedral in Kiev, the foundation of the Caves monastery, and the transmission of "Cyrillo-Methodian" tradition into Rus'.

\footnotetext{
${ }^{1}$ The opinion according to which the writings of Ilarion, Kliment and Kirill ought to be considered the most important for the period is well-known. It was held by such distinguished researchers of Russian spirituality as Georgy Fedotov, Georgy Florovsky and Dmitry Likhachov. The latter called them the best representatives of Old Russian byzantinism. Florovsky also referred to this notion but in a pejorative sense: the Old Russian Hellenism that marked works of these authors is seen by him as indicating their lack of originality. Сf.: Д.С. Лихачев, Развитие русской литературы X-XVIII в., [in:] IDEм, Избранные работы, Ленинград 1987, р. 93; Г.В. Флоровский, Пути русского богословия, Москва 2009, р. 21; Г.П. ФЕдотов, Русская религиозность. Христианство Киевской Pуси X-XIII вв., [in:] IDEм, Собрание сочинений в двенадиати томах, vol. X, Москва 2001, p. 68.
} 
It is the Slavophilism, a $19^{\text {th }}$ century trend in the Russian philosophy, that has to be attributed with particular merits in promoting the notion that the peculiar for Kievan Rus' way of life was ideal in terms of morals, outlook, and religion, as well as in implanting into the national consciousness the idea of Russian exceptionalism (combination of byzantinism with "Slavonic sensitivity"). Slavophiles, such as Ivan Kireevsky (1806-1856), maintained that it was in this epoch that the "integral life" ${ }^{2}$ in culture and popular consciousness (i.e., a holistic and organic perception of reality - of man, world, and God) was really attainable. From the Slavophile point of view the pre-Mongol period thus appears as exceptional and, importantly, favourable for the intellectual, philosophic and theological activity.

The above-mentioned activity was centred around the Holy Scripture. The Bible played in Kievan Rus' the role of a paramount source, despite the fact that its first full translation, by Gennady and his literary circle, appeared as late as 1499. Before that, only certain fragments had been available and these had been used for liturgical purposes. In the $11^{\text {th }}$ century there existed and functioned a version of the Holy Scripture translated within the "Cyrillo-Methodian" tradition, but it was not complete and mostly used during liturgy. In the second half of the $11^{\text {th }}$ century there appeared the Arkhangelsk Gospel and the Ostromir Gospel of the aprakos type, that is an abbreviated version of parts of the Gospels ordered as they would be read during services. Whereas in the $12^{\text {th }}$ century one observes an increase in translation and compilation of biblical sources in Old Rus'. Most importantly, Halicz Gospel (1144), containing the full text of the four Gospels, becomes available. However, the liturgical, that is partial, type of Bible remains the most popular. This includes e.g. Prolog, i.e. Old Rus' version of synaxarion and menaions that is the collections of lives of saints, Apostle-aprakos, containing Acts of the Apostles, Apostolic Letters and the Book of Revelation, Grigorovichev Parimejnik (fragments of the Old Testament books) and Psalter.

Both local and more global events were explained through biblical imagery. However, it should be emphasised that the quotations were not always strict. Wacław Hryniewicz states that the Old Russian writers did not quote fragments from the Holy Scripture word for word ${ }^{3}$, they often quoted from memory and complemented the translations with apocrypha. The apocrypha were very popular in Old Rus', which shows that the Old Rus' way of thinking was of mythological rather than rational character. The biggest and the oldest collection of apocrypha, containing e.g. apocrypha on Solomon, on Thomas the Apostle, and on Adam and Eve, was included in Paleya Tolkovaya (between the $11^{\text {th }}$ and $13^{\text {th }}$ centuries) and later in Paleya Hronograficheskaya (the $14^{\text {th }}$ century). Apocrypha is an example

\footnotetext{
${ }^{2}$ И.В. КИРеЕвскИЙ, О характере просвещения Европы и о его отночении к просвещению России, [in:] IDEм, Полное собрание сочинений, vol. I, Москва 1911, p. 218.

${ }^{3}$ A. Naumow, Apokryfy w systemie literatury cerkiewnosłowiańskiej, PKSł 36, 1976, p. 30.
} 
of mythologisation of experience, but when myths are used to transfer us to the spiritual level of consciousness (Joseph Campbell), the development of spirituality leads to the development of sensitivity and hence to wisdom and philosophy.

Ilarion of Kiev is the first figure, whose activity seems to be philosophicallyoriented in a sense described above. There is relatively more known about his life and work compared to others, owing to the preserved historical sources and extensive modern research ${ }^{4}$. The main source is the oldest Rus' chronicle: Primary Chronicle (from the beginning of the $12^{\text {th }}$ century). The authorship of this chronicle is attributed to Nestor (1050-1114), a monk from Caves monastery. We read there that Ilarion was a presbyter and a monk in a newly created Caves monastery in Kiev and the first Rus' metropolitan, appointed by Yaroslav the Wise (978-1054) in 1051:

Prince Yaroslav was fond of Berestovo and the Church of the Holy Apostles there situated. He gathered a large company of priests, among whom was a presbyter named Ilarion, a virtuous man, learned and ascetic ${ }^{5}$.

There is no information with regard to his education but it is known that

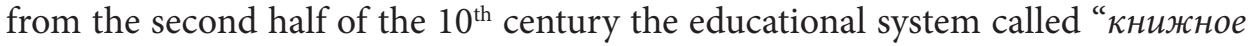

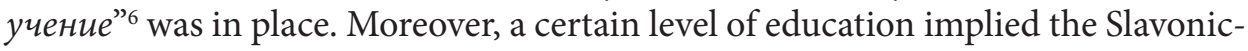
Greek bilingualism because (as researchers suggest) a knowledge of Greek was a pre-requisite for learning the Old Church Slavonic, which functioned as the liturgical and literary language in Kievan Rus ${ }^{37}$.

Ilarion authored one work entitled On Law and Grace (ca. 1037), which from a formal point of view is a solemn homily. Homilies are often of oral character and it seems that this was also the case of On Law and Grace. It is likely that the sermon was given on the occasion of consecration of the Saint Sophia's Cathedral in Kiev. The Saint Sophia's Cathedral was a special place, which symbolised the identity of Old Rus'. It was a place where the opinions were shaped, the religious and intellectual heart of Kiev, which in the $11^{\text {th }}$ century had an ambition of becoming a cultural centre equal to Constantinople and independent of it ${ }^{8}$.

\footnotetext{
${ }^{4}$ Слово о законе и благодати, [in:] Библиотека литературы Древней Руси, ed. Д.С. ЛихАчев, Л.А. Дмитриев, А.А. АлексеЕв, Н.В. Понырко, vol. I, Санкт-Петербург 1997; Идейно-философбское наследие Илариона Киевского, ed. В.В. Мильков, vol. I-II, Москва 1986.

${ }^{5}$ The Russian Primary Chronicle. Laurentian Text, trans. et ed. S. Hazzard Cross, O.P. Sherbowitz-Wetzor, Cambridge 1953, p. 139.

${ }^{6}$ В.В. Кусков, История древнерусской литературы, Москва 1982, р. 29.

${ }^{7}$ С. Б.А. Успенский, Языковая ситуация Киевской Руси и ее значение для истории русского литературного языка, Москва 1983, р. 18-21.

${ }^{8}$ Cf.: М.В. Левченко, Очерки по истории русско-византийских отночений, Москва 1956, р. 444; Д.С. ЛихАчвв, Великое наследие. Классические произведения литературы Древней Руси, Москва 1979, p. 45.
} 
On Law and Grace is customarily divided into four parts: 1) On Law and Grace, 2) How Grace spreads and reaches Rus', 3) The encomium of Vladimir 4) The prayer (Confession of faith), where the author indicates that he knew of and identified himself with the results of the councils and the teachings of the Church Fathers. It is the first three parts that are important from a philosophical point of view. The content of the first part indicates that Ilarion viewed himself as a maintaining the tradition of Byzantine theology. Writing about the superiority of the New Testament over the Old and in his philosophical formulation of the doctrine of God's Grace, he was most likely inspired by Homilies on Jews and Judaizing Christians (387) by John Chrysostom (350-407), a Byzantine theologian and speaker. Homilies were divided into eight parts in which the author contrasted two rivalling communities (politeias) in Antioch: Christian and Jewish. The Church Father portrayed the Jews and their religious holidays as devoid of values (the first homily), so anyone involved in the Jewish proselytism (especially "judaizing Christians" or "Antiochean half-Christians") was condemned by him (third and eighth homilies). All this was aimed to prove the superiority of Christian doctrine and its future social victory ${ }^{9}$.

It should be mentioned that the works of John Chrysostom were treated with reverence in the Old Rus'. The Church Father is mentioned in the anthology of aphorisms translated from Bulgarian and compiled by a deacon John for the Grand Prince Sviatoslav of Kiev (1027-1076), called Izbornik of Sviatoslav from 1076: Listen to the lives of Saint Basil, Saint John Chrysostom and Saint Cyril the philosopher ${ }^{10}$. Earlier, at the end of the $9^{\text {th }}$ century (in Bulgaria), fragments of John Chrysostom's works appeared in the so-called Golden stream (Златоструц̆).

Ilarion's sermon refers to the Old Testament parable of Hagar and Sarah (Gn 15,1-21,34), with its allegorical interpretation aimed at presenting the notion of God's Grace. Sarah was Abraham's wife, who could not have offsprings. However, Abraham had a slave named Hagar and at Sarah's will she bore him a son, Ishmael. This occurrence has been compared to the moment of receiving the Ten Commandments on Mount Sinai by Moses. Ishmael was identified with the Law, the announcement. In old age, however, Sarah gave birth to a son, Isaac, who in turn, has been identified with Jesus the Godman. Isaac (Jesus) was free while Ishmael (the Jews) was a slave and limited by law. Jews thanks to the Law, have gained only forgiveness for their behaviour, while Christians, thanks to God's Grace, have received salvation. The value of the Law has been diminishing, while the Christian promise of salvation has been growing owing to the sacrifice of the Christ. The homily presents a number of comparisons, "Christological antitheses" which prove the two natures of Jesus: one of the Trinity, in two natures,

\footnotetext{
${ }^{9}$ Cf. Discourses against judaizing Christians, trans. P.W. HARKINs, Washington 1979, passim.

${ }^{10}$ Из Изборника 1076 года, [in:] Библиотека литературы..., vol. II, Санкт-Петербург 1999, http://lib.pushkinskijdom.ru/Default.aspx?tabid=2167 [28 V 2016].
} 
divine and human. He was fully human, becoming man not merely in appearance; yet not merely man, for in His divinity He was also fully God ${ }^{11}$. Ilarion seems to have a deep awareness of the idea of Godmanhood of Jesus, the divine logos in human flesh, although not using there such a sophisticated word like "Logos". The author allegorically illustrated the dogma of the hypostatic union canonical from 451 (Council of Chalcedon).

In the Orthodox tradition and from a theological and philosophical points of view, God's Grace is identified with God himself: Truth and Grace is the servant of the age to come, of life incorruptible ${ }^{12}$. The Orthodox theology identifies it with the non-created energies, God's powers through which God manifests His presence to man and the world. Man, by experiencing God's Grace, becomes free and redeemed (e.g. deified). Also, the entire Old Rus' nation is encompassed by God's Grace - and this nation is the subject of the second part.

Ilarion compares pagan times with a dried-up ground: our land was parched and desolate $^{13}$, which only became fertile after the dawn of Christianity. People blind, deaf and poor in spirit are becoming aware and wise: He [God] brought us unto the knowledge of the Truth ${ }^{14}$. Christian Old Rus' is treated as a fully-fledged nation inferior to none with her history recognised as a part of the general history of humankind. Owing to Christianity, the state obtained a new identity and a chance for a brighter future. The argumentation involved the figure of Vladimir the Great, the ruler responsible for the baptism of Old Rus. Vladimir was compared there to Constantine the Great given the historical importance of his deed. Vladimir's Christianisation of Old Rus' was, in the eyes of Ilarion, a deed that put Vladimir on par not only with the Byzantine emperor but also with the Evangelists:

\footnotetext{
Rome with the voices of praise, praises Peter and Paul, for through Peter and Paul Rome came to believe in Jesus Christ, Son of God. Asia and Ephesus and Patmos praise John the Theologian. India praises Thomas, Egypt praises Mark: every land and every city and every nation honours and glorifies its teacher that taught it the Orthodox faith. We too, therefore, let us praise to the best of our strength, with our humble praises, him whose deeds were wondrous and great, our teacher and guide, the great kagan of our land, Volodimer, the grandson of Igor of old and son of the glorious Svjatoslav. When these reigned in their time, their renown spread abroad for their courage and valour; and still they are remembered, renowned even now for their victories and might. For they ruled not some feeble, obscure, unknown land, but in this land of Rus', which is known and renowned to the ends of the earth ${ }^{15}$.
}

With the Christianisation of Old Rus' Vladimir (having accepted the baptismal name Basil) gave evidence of his wisdom, justice and kindness of heart. This

\footnotetext{
${ }^{11}$ Sermons and rhetoric of Kievan Rus'..., p. 10.

${ }^{12}$ Ibidem, p. 4.

${ }^{13}$ Ibidem, p. 14.

${ }^{14}$ Ibidem.

${ }^{15}$ Ibidem, p. 17-18.
} 
wisdom turned out to be the legacy of Great Princess Olga (890-969), who is considered as one of the first to accept Christianity from the Byzantine Emperor $^{16}$. In turn, Vladimir's work was continued by his son Yaroslav (baptismal name George) by erecting the Saint Sophia's Cathedral in Kiev, the city, shining in splendour ${ }^{17}$, which became the symbol of Old Rus' enlightenment.

Ilarion mythologised this event, as he believed that the Christianisation meant a good and successful future for Old Rus' - as Old Rus' became equal to other nations before God and was given a chance of participating in God's Grace. This does not involve the notion of a chosen nation - all nations are equally important before God. There is, however, a tendency to make a distinction, as all the comparisons he makes turn out to be in favour of Old Rus' (e.g. Vladimir the Great - Constantine the Great).

Ilarion's work, according to the researchers, was the first document of Russian historical self-consciousness ${ }^{18}$. The Old Rus' nation was described as the herd of Jesus the shepherd and included in the universal history of salvation. Therefore local themes are interwoven with the more global ones. It is clear that the author of $\mathrm{On}$ Law and Grace had an evangelising streak in him, which, after all, seems quite natural given the position he held: Ilarion interpreted, allegorised, taught history of his land, and felt a deep sense of responsibility to fulfil his mission as a guide of Old Rus' and its philosopher, a creator of national ideas.

An additional reason why we can consider him a philosopher is his language, which was reaching out for philosophic metaphors, e.g. humankind was (...) like a fouled vessel ${ }^{19}$; or Grace as sun's warmth warmed the earth ${ }^{20}$. Here we encounter a simile of light. Holiness and Grace, as everything that comes from God, was associated with light. So, in the case of homily On Law and Grace, one can speak of traces of the metaphysics of light, the light that liberates and delivers from bondage: Yet God had mercy upon us and the light of understanding shone forth upon us, that we might know Him ${ }^{21}$. But in as much as Ilarion was distinctly sensitive in abstract and metaphysical matters, he remained a practical philosopher and an astute theologian. So, his considerations were confined to the following postulates: a necessity to abdicate from the material side of life: we gave ourselves over to carnal lust, we became slaves to sin and the cares of the world ${ }^{22}$ and the reality of truth, both eternal and practical: (...) Christians' salvation is generous and beneficent extending to all corners of the earth ${ }^{23}$.

\footnotetext{
${ }^{16}$ The Russian Primary Chronicle..., p. 82.

${ }^{17}$ Sermons and rhetoric of Kievan Rus'..., p. 25.

${ }^{18}$ Cf. С. Сендерович, Слово о законе и благодати как экзегетический текст, ТОДЛ 51, 1999, p. 43.

${ }^{19}$ Sermons and rhetoric of Kievan Rus'..., p. 4.

${ }^{20}$ Ibidem, p. 7.

${ }^{21}$ Ibidem, p. 15.

${ }^{22}$ Ibidem, p. 27.

${ }^{23}$ Ibidem, p. 7.
} 
The ideas from the sermon On Law and Grace are picked up in An Epistle written by Kliment, metropolitan of Rus', to Foma the Presbyter, with interpretations by the monk Afanasij (ca. 1147) authored by Kliment Smolatič. Kliment was the second, after Ilarion, metropolitan of Kiev of local origin (he performed this function between 1147-1154). In Hypatian Chronicle (from the $13^{\text {th }}$ century) he is called a "great philosopher" ${ }^{24}$, which should be understood as a description of an exceptional, active writer, a bookman. There is a suggestion that he might have authored some philosophical works but these have not survived to modern times ${ }^{25}$. He was surrounded by people with Greek-styled education, indicating that he might have had such education himself. Neither Kliment's personality nor his works have been subject of a large interest among Western researchers and there is no publication describing his literary output (with the exception of professor Simon Franklin from Harvard). In Russian too, there is only one monograph on the topic, written by Nikolay Nikolsky in 1892 and a translation from the Old Church Slavonic made in the Institute of Russian Literature (Russian Academy of Sciences, the Pushkin House).

The Epistle, formally, was addressed to Foma, who was one of the trustees of the Grand Prince of Kiev Izjaslav II Mstislavič (1096-1154) and to the circle of disciples of Gregory, about whom information is scarce, but in practice it involved the Prince himself: But if I did write, then it was not to you but to the prince ${ }^{26}$. We know that this work was read out to the Prince and his entourage but we do not know what was the Prince's reaction. In terms of form and topic, this text, similarly to On Law and Grace, can be described as solemn homiletics combining local - Old Rus'related - themes with more general ones - pertaining to the Christian world at large. Apart from Byzantine influences, Kliment may have been inspired by Shestodnev (of the $10^{\text {th }}$ century) by bishop John the Exarch - as he followed John in reproducing the name of a sea creature - (ехион морьскиц̆), the abilities of which (to cope with storms, winds and thunders) were seen as a testimony to God's wisdom and kindness ${ }^{27}$. Shestodnev was a type of Hexameron, where the author contemplated the secret of world creation, referring to various Byzantine theologians e.g. John of Damascus and the Cappadocian Fathers. Together with strictly theological ideas, one also finds there philosophical considerations as well as those relating to the natural world - John the Exarch often quotes and summarises parts of Aristotle's philosophy (describing geography, the heavenly bodies and the soul) ${ }^{28}$.

\footnotetext{
24 Летопись по Ипатьевскому списку, Санкт-Петербург 1871, р. 241; Е.Э. Гранстерн, Почему митрополита Климента Смолятича называли «Филособом», ТОДЛ 25, 1970, р. 20-28.

${ }^{25}$ Cf. Н. Никольский, О литературных трудах митрополита Климента Смолятича, писателя ХІІ века, Санкт-Петербург 1892, р. 3.

${ }^{26}$ Sermons and rhetoric of Kievan Rus'..., p. 31.

${ }^{27}$ Ibidem, p. 49.

${ }^{28}$ Cf.: Из «Шестоднева» Иоанна экзарха болгарского, trans. Г.М. ПрохоровА, [in:] Библиотека титературь..., vol. II, http://lib.pushkinskijdom.ru/Default.aspx?tabid=2166 [28 V 2016];
} 
It seems that in the Epistle the definition and essence of "philosophy" and "philosophising" is broadened. Figures such as Plato, Aristotle and even Homer are mentioned in the context of the above notions:

You say to me: «you write so as to glorify yourself, making yourself out to be a philosopher». Yet the fault is primarily your own! As if I ever wrote any such thing to you! But neither did I write nor would I write thus! And yet you say: «You write philosophically», while in fact you yourself wrote most falsely, as though I had abandoned the revered Scriptures and had instead written using Homer and Aristotle and Plato, who were renowned in the colonnades of the Hellenes ${ }^{29}$.

At first, it seems that Kliment is merely distancing himself from the pagan cultural authorities. But given the background of his polemic and his plausible intellectual horizons we might suggest that he did in fact value Plato, Aristotle and Homer more than his ignorant opponent, since the first two of them were valued by John Chrysostom and Gregory the Theologian, whom Kliment regards as authorities.

Philosophy helped Kliment to discover divine secrets, hence he is not ashamed of calling himself a philosopher:

I do not think what I wrote was «philosophy». Christ said to the holy disciples and apostles: "Unto you it is given to know the mysteries of the kingdom, but to the rest in parables» $($ Lc 8,10$)$. Dear Foma, is this the "philosophy» through which I seek glory from the men? ${ }^{30}$.

Kliment addressed potential misunderstandings and explained that philosophising is not just trying to be smart, looking for attention and a sign of pride. The wisdom of pagan philosophers, especially of Plato, can be used in allegorical interpretation of the Holy Scripture and in explaining the truths of the faith. This was, after all, done by the early Christian apologists writing in Greek - Clement of Alexandria, Origen, Justin Martyr. On such practices, the Alexandrian school of Christian theology was based. Kliment does not mention these figures but perhaps he was familiar with their views. The only available Slavonic translations of fragments of Plato's work were contained in the already-mentioned Shestodnev by John the Exarch, a Byzantine compilation of aphorisms and sayings by Greek philosophers and the Church Fathers called Melissa, the Greek original of which was translated in the $12^{\text {th }}$ century, that is when Kliment probably had been already dead. Hence, he may have known some extracts from Plato's works in Greek. However, there is

Г.С. БАРАНКОВА, Античная философия, мифология, научные знания в древнеславянских переводных памятниках и выработка научной терминологии, [in:] Философские и богословские идеи в памятниках древнерусской мысли, еd. МН. Громов, Москва 2000, p. 25-27.

${ }^{29}$ Sermons and rhetoric of Kievan Rus'.., p. 31.

${ }^{30}$ Ibidem, p. 45. 
no doubt that Kliment read the works of John Chrysostom, as certain fragments of his works had been available in Old Rus' as early as in the $11^{\text {th }}$ century (or perhaps even in the $9^{\text {th }}$ century).

Kliment, to prove his respect towards the Bible and his excellent knowledge of it, undertook an allegorical interpretation of the fragments on Divine Wisdom (Prv 9,1) and the Judah and Tamar (Gn 38,12-23). An allegorical interpretation of the latter Old Testament fragment assumes that God is symbolised by wisdom and humankind is symbolised by the house, since Christ entered the house as he assumed a body, and the seven columns symbolise seven general councils. This interpretation entails that the Divine Wisdom found a harbour and the best way of expressing itself in humankind, hence the task of man is to cultivate it.

The cult of Saint Sophia has been exceptionally strong in the consciousness of the Kievan Rus. The Old Rus' depictions of St. Sophia were as multifaceted as the Byzantine ones. Slavs, especially the Eastern and Southern ones, perceived her in their own way, which reflected their type of sensitivity. At the turn of the $19^{\text {th }}$ century, the cult of St. Sophia acquired a philosophical dimension - Russian sophiologists (Vladimir Solovyov, Pavel Florensky, Sergey Bulgakov and Aleksei Losev) interpreted the image of St. Sophia within the framework of their theological and philosophical, iconographic, hesychastic and onomatodoxical analyses.

The Epistle is not the only work by Kliment (there is also a number of answers to the so-called Questions of Kirik the Novgorodian and Sermon on love, first half of the $12^{\text {th }}$ century), yet it is this text that gives evidence of the philosophical dimension of this author. Among other sources, Kliment could have been inspired by a Letter to Titus ( $5^{\text {th }}$ century) of Pseudo-Dionysius the Areopagite, in which the author explained his understanding of the Divine and Mystical Truth, unapproachable by the profane ${ }^{31}$ and a variety of symbolic representations of Divinity, i.e. Images of God. One of the symbolic representations of Divinity turns out to be the image of the Divine Wisdom (which also appealed to Kliment) that invites to the feast and distributes the food, i.e. the gifts from God, life-giving and nourishing and perfecting ${ }^{32}$.

The reception of the Corpus Areopagticum in Kievan Rus' seems to be significant to the investigation on the development of philosophical ideas there. A manuscript of the translation of the Corpus Dionisiacum made by a Serbian monk Isaiah in 1371 was imported from the Balkans to Rus' only in the $19^{\text {th }}$ century. But researchers believe that a translation had been known there earlier ${ }^{33}$. The issue had been discussed by the first Russian female philosopher Maria Bezobrazova (1856-1914), as well as by the contemporary scholars: Anatoly Ticholaz and Gelian Prokhorov ${ }^{34}$.

\footnotetext{
${ }^{31}$ The Works of Dionysius the Areopagite, trans. J. PARKer, London 1897, p. 169.

${ }^{32}$ Ibidem, p. 176.

${ }^{33}$ Cf. A. Ticho£az, Platonizm w Rosji, trans. H. Rarot, Kraków 2004, p. 36-37.

${ }^{34}$ Cf.: Г.М. Прохоров, Сочинения Дионисия Ареопагита в славянской рукописной традииии, [in:] IDEм, Русская и армянская средневековые титературы, Ленинград 1982; М.В. БезоврАзовА, Творения Святого Дионисия Ареопагита, Санкт-Петербург 1898.
} 
Kliment Smolatič was a representative of the same trend in Old Rus' literary activity as Kirill of Turov (1130-1182). The characteristic feature of this current was an attempt at synthesis of Greek loans (metaphors, patterns, epithets) with the Old Rus' native outlook. It is not unlikely that during Kirill's times he has been taught in Turov by the Byzantine scholars gathered around a Greek princess Barbara (died 1190), who resided there, being the second wife of Sviatopolk Yurevič. Kirill's works, which include paschal homilies, ascetic writings and prayer-related texts, are considered to be least philosophical and he is viewed rather as a poet, whose writings do not emphasise the intellectual element. Since his theological legacy is described in detail, e.g. by Simon Franklin ${ }^{35}$, let us just focus on a single text entitled The tale of the Body and the Soul (On the Lame and the Blind) (dated to the 1160s) that contains a number of philosophical theses worth considering. The text begins with the praise of understanding the books (книжное знание): Sweet is the honeycomb, and sugar is good; but understanding the books is better than both, for the books are treasure houses of eternal life $e^{36}$. We deal here with the advocacy of wisdom in the sense of conscious and ample knowledge of the sacred texts and the ability of their proper (allegorical) interpretation. Such knowledge ennobles the soul, the mind and the heart. A man, who acquired this knowledge is the master of himself and his fate, moves away from the possibility of sin, and more importantly, becomes predisposed to partake in God's Grace.

The allegory of soul and body was based on the biblical story of mischievous farmers, who had robbed their neighbour's orchard (Mt 21,33-41). In the Bulgarian Empire, it was known during the reign of Symeon I the Great, that is in the $9^{\text {th }} / 10^{\text {th }}$ century $^{37}$. There was a householder, who had a vineyard and was looking for night guards of his crops - eventually he chose a blind one and a lame one as he thought that they would not be able to rob him, given their disabilities. As it turned out, however, the blind one put the lame one on his back and with the lame one's directions they were able to go over the fence and rob the orchard. When the householder asked them about it in the morning, they cast aspersions at each other.

According to Kirill, the householder symbolised God, the lame one symbolised the body, the blind one symbolised the soul, the vineyard symbolised the world, and the fence symbolised divine laws. The philosophical content of this parable can be reduced to the thesis on the unity of the soul and the body. Both body and soul are equal parts of man, they function in collaboration and neither of them can be rejected. Sin is a spiritual burden, it is not only the body but also the soul that is responsible for it - both these elements constitute a man. Similar topics

\footnotetext{
${ }^{35}$ Sermons and rhetoric of Kievan Rus'..., p. lxxx-xciv.

${ }^{36}$ Ibidem, p. 55.

${ }^{37} \mathrm{Cf} .:$ Сон Джонг Со, Еще раз о соотномении двух древнерусских редакиий Притчи о слепие и хромие, ТОДЛ 54, 2003, р. 390; И.П. Ермин, Притча о слепие и хромце в древнерусской письменности, ИОРЯС 30, 1925, р. 323-352.
} 
had been dealt with before, long reflections on the relation between body and soul are contained in an anonymous collection of translations, the so-called Izbornik of 1073, where we can read that the soul and the body are one: Unity of the being (essence) takes place in individual substances, unity of individual substances takes place in beings (essences) like in the case of soul and body ${ }^{38}$. The Izbornik (1073) is a text on natural philosophy, hence the topic of the soul and the body is analysed in the logical context (apart from the religious one). The true being, that is what exists, that is cymee, can be divided into concrete and accidental beings. Hypostases are concrete beings. The essence can exist without hypostasis but a hypostasis cannot exist without essence. Peter is a hypostasis but only when he also has essence, e.g. being a man.

In the case of Christ, there is no similar parallelism. In contrast to Ilarion, who emphasised the godman nature of Christ, Kirill did not devote much attention to the problem of the human aspects of Jesus. Through Jesus, God manifests the will to become known to man. Allegorically, this is expressed by the open orchard gates:

The unclosed Gateway is the wondrous ordering of God's nature. As it is said: «Know the Creator by His creation» (Rom 1,19-20). But you must understand that this means not His quality but His magnitude and might, the glory and the grace which He created in His care for the high and the low, for the visible and invisible. ${ }^{39}$

This fragment shows that Kirill was aware (or perhaps it was just his intuition) of the essence and energies of God, differentiated within Him. Man gets to know God through His actions that manifest themselves in the order and harmony of the surrounding world.

Ilarion of Kiev, Kliment Smolatič, and Kirill of Turov were not the only significant thinkers of Kievan Rus'. Vladimir Monomach (1053-1125), Theodosius of the Caves (1029-1074), Daniel the Immured $\left(12^{\text {th }}-13^{\text {th }}\right.$ centuries), Nicephorus I ( $\uparrow 1121)$ and the chroniclers also deserve to be noted. Regarding the latter, Dmitry Likhachov said: [they] undertook a comprehensive attempt to approach the history from the Russian perspective, while expressing their views in historiosophical and cosmological ways ${ }^{40}$. The inspiration for the chroniclers, both Byzantine and Old Rus', was the Bible: the chronicler expresses his feelings in the language of the Bible $e^{41}$. Old Rus' chronicles were partly inspired by the Byzantine ones - the

\footnotetext{
${ }^{38}$ Из Изборника 1073 года, trans. Г.М. Прохоров, [in:] Библиотека литературы..., vol. II.

${ }^{39}$ Sermons and rhetoric of Kievan Rus'..., p. 58.

${ }^{40}$ Д.С. Лихачев, Великое наследие. Классические произведения титературы Древней Руси..., p. $48-52,105$.

${ }^{41}$ W. HryniewiCz, Staroruska teologia paschalna $w$ świetle pism św. Cyryla Turowskiego, Warszawa 1993, p. 80.
} 
chronicle of John Malalas emerged in Rus' in the $10^{\text {th }}$ century and the chronicle of George Hamartolos in the $11^{\text {th }}$ century - and partly by "the Slavic sensibility".

Old Rus' philosophical thought expressed in the works of Ilarion, Kliment and Kirill emphasised the religious, ethical, eschatological, cosmological and metaphysical concepts, while putting little stress on formalized rational reasoning. Georgy Fedotov wrote that religious cosmology and history evident in the works of the above-mentioned thinkers were founded on eschatological visions. These authors appear to be more of the moralizers than ethicists; more the exponents of the Christian economy of salvation than metaphysicians.

Consequently, the thought we observe in Kievan Rus' is pre-philosophical rather than philosophical (in the sense of a theological philosophy found in Byzantium), but the time between $11^{\text {th }}$ and $13^{\text {th }}$ centuries can be defined as the formative time for Russian outlook. That is why it can be seen as an integral part of the study of the sources of Russian philosophy (especially Russian religious philosophy).

\section{Bibliography}

\section{Sources}

Discourses against judaizing Christians, trans. P.W. HARKINs, Washington 1979.

Sermons and rhetoric of Kievan Rus', trans. S. Franklin, Harvard 1991.

The Russian Primary Chronicle. Laurentian Text, trans. et ed. S. Hazzard Cross, O.P. Sherbowitz-Wetzor, Cambridge 1953.

The Works of Dionysius the Areopagite, trans. J. PARKer, London 1897.

Из «Шестоднева» Иоанна экзарха болгарского, trans. Г.М. Прохорова, [in:] Библиотека литературы Древней Руси, vol. II, Санкт-Петербург 1999.

Из Изборника 1076 года, [in:] Библиотека литературы Древней Руси, еd. Д.С. Лихачев, Л.А. Дмитриев, А.А. АлексеЕв, Н.В. Понырко, vol. II, Санкт-Петербург 1999.

Летопись по Ипатьевскому списку, Санкт-Петербург 1871.

Слово о законе и благодати, [in:] Библиотека титературы Древней Руси, ed. Д.С. Лихачев, Л.А. Дмитриев, А.А. АлексеЕв, Н.В. Понырко, vol. I, Санкт-Петербург 1997.

\section{Secondary literature}

Hryniewicz W., Staroruska teologia paschalna w świetle pism św. Cyryla Turowskiego, Warszawa 1993. Naumow A., Apokryfy w systemie literatury cerkiewnosłowiańskiej, PKSł 36, 1976, p. 1-122.

Thomson F.J., Quotations of Patristic and Byzantine Works by Early Russian Authors as an Indication of the Cultural Level of Kievan Russia, SGa 10, 1983, p. 65-102.

Ticho£az A., Platonizm w Rosji, trans. H. Rarot, Kraków 2004, p. 36-37. 
БАРАнкова Г.С., Античная философия, мифология, научные знания в древнеславянских переводных памятниках и выработка научной терминологии, [in:] Философские и богословские идеи в памятниках древнерусской мысти, ед. М.Н. Громов, Москва 2000, p. 22-48.

Безовразова М.В., Творения Святого Дионисия Ареопагита, Санкт-Петербург 1898.

ГРАнСТеРн Е.Э., Почему митрополита Климента Смолятича называли «Философом», ТОДЛ 25,1970 , p. $20-28$.

Ермин И.П., Притча о слепще и хромие в древнерусской письменности, ИОРЯС 30, 1925, p. 323-352.

КИРеввскиЙ И.В., О характере просвещения Европы и о его отношении к просвещению России, [in:] IDEм, Полное собрание сочинений, vol. I, Москва 1911, p. 174-222.

Кусков В.В., История древнерусской литературы, Москва 1982.

Левченко М.В., Очерки по истории русско-византийских отношений, Москва 1956.

Лихачев Д.С., Великое наследие. Классические произведения литературы Древней Руси, Москва 1979.

Лихачев Д.С., Развитие русской литературы X-XVIII в., [in:] IDEM, Избранные работы, Ленинград 1987, р. 24-260.

Никольский Н., О литературных трудах митрополита Климента Смолятича, писателя ХІІ века, Санкт-Петербург 1892.

Прохоров Г.М., Сочинения Дионисия Ареопагита в славянской рукописной традиции, [in:] IDEм, Русская и армянская средневековые литературы, Ленинград 1982.

СЕндеРович С., Слово о законе и благодати как экзегетический текст, ТОДЛ 51, 1999, p. 43-57.

Сон Джонг Со, Еще раз о соотночении двух древнерусских редакиий Притчи о слепце и хромце, ТОДЛ 54, 2003, p. 390-401.

УСпенский Б.А., Языковая ситуация Киевской Руси и ее значение для истории русского титературного языка, Москва 1983.

Федотов Г.П., Русская религиозность. Христианство Киевской Руси Х-ХІІІ вв., [in:] IDEм, Собрание сочинений в двенадиати томах, vol. X, Москва 2001, p. 8-396.

Флоровский Г.В., Пути русского богословия, Москва 2009.

\begin{abstract}
The article is an attempt to critically evaluate the manifestations of the philosophical culture sprouting in Rus'. With the baptism in the Byzantine Rite, Rus' in the $10^{\text {th }}$ century joined the family of Christian nations and defined the future direction of her own cultural development. The Middle Ages in Rus' were eminently theocentric. Literature (which was mostly translated from the Greek in Bulgarian monasteries) had a religious character. Sacral content, assimilated in Rus' mainly through the Old Church Slavonic (due to the scarce knowledge of Greek) had a decisive influence on formation of the philosophical worldview of Rus' intellectual elite. The Bible thus became the main reference framework for the first Rus' thinkers-philosophers: Ilarion of Kiev ( $\dagger 1055)$, Kirill of Turov $(\dagger 1183)$ and Kliment Smolatič ( $\dagger 1164)$. Ilarion of Kiev, the first metropolitan of the Kievan Rus' in his rhetoric work (which postulated the superiority of the New Testament to the Old) expressed a philosophical thesis of the equality of all Christian nations before God. Kliment Smolatič, the second metropolitan of Rus', in his Letter to Presbyter Foma, defended the allegorical method
\end{abstract}


of interpretating the Bible. Kirill of Turov, in his turn, in his Parable of the human soul and body allegorically tried to answer the question about the relationship of the body and the soul. For the Rus' thinkers the content of the Bible served as a pretext for philosophical reflection, e.g. on the role of man in the universe, on the nature of reality, on the relation between matter and spirit. In their works we find the beginnings of the theory of knowledge, metaphysics, ethics, and aesthetics.

Keywords: Kievan Rus', Russian philosophy, Byzantine culture, Orthodox religion, Ilarion of Kiev, Kliment Smolatič, Kirill of Turov.

Justyna Kroczak

Uniwersytet Zielonogórski

Wydział Humanistyczny

Instytut Filozofii

Zakład Historii Filozofii

al. Wojska Polskiego 71a

65-762 Zielona Góra, Polska/Poland

j.kroczak@ifil.uz.zgora.pl 